\title{
Pseudomonas putida Stimulates Primordia on Agaricus bitorquis
}

\author{
Nelson B. Colauto ${ }^{1} \cdot$ Terry R. Fermor $^{2}$ - Augusto F. Eira ${ }^{3} \cdot$ Giani A. Linde $^{1}$
}

Received: 16 September 2015/ Accepted: 1 December 2015/Published online: 8 January 2016

(C) Springer Science+Business Media New York 2016

\begin{abstract}
Casing layer is one step of Agaricus bisporus cultivation where there is a competitive environment with a high number of microorganisms and diversity interacting with mycelia. It is suggested that a minimal community of these microorganisms would be necessary to stimulate fructification. However, A. bisporus is not able to produce primordia in sterile casing layers or Petri dishes. Thus, the objective of this study was to characterize bacterial microbiota of casing layers from A. bisporus cultivation, isolate, identify and characterize the bacteria responsible for the stimulation of primordium and their action mechanism using Agaricus bitorquis as a primordium stimulation model. Bacterial and Pseudomonas spp. communities of different casing layers of $A$. bisporus cultivation were collected and quantified. It was concluded that Pseudomonas spp. corresponds to $75-85 \%$ of bacterial population of the casing layers in A. bisporus cultivation and among those $12 \%$ are Pseudomonas putida. Four biochemical assays were used to identify $P$. putida. In vitro primordium stimulation of living $P$. putida and non-living bacterial suspensions, after chemical or physical treatments, was tested using A. bitorquis as a primordium stimulation model. Primordium stimulation assay was registered by photographs, and micrographs of
\end{abstract}

Augusto F. Eira-in memoriam.

Nelson B. Colauto

nbc@unipar.br

1 Postgraduate Program in Biotechnology Applied to Agriculture, Paranaense University, Umuarama, PR, Brazil

2 Horticulture Research International, Wellesbourne, Warwick, UK

3 Mushroom Production, Paulista State University, Botucatu, SP, Brazil vertical cut of primordium were registered by scanning electron microscope. Interaction of living $P$. putida with $A$. bitorquis mycelia is capable of stimulating primordial instead of non-living bacterial suspensions. Stimulation of $A$. bitorquis primordia does not imply or is related to mycelial growth inhibition, but a hierarchical relation of primordium succession and development is suggested.

\section{Introduction}

Casing layer is one step of Agaricus bisporus (J. E. Lange) Imbach cultivation in which peat, soil, and/or other alternative materials are placed on colonized compost to stimulate fructification and the developing basidiocarps; without it there would be a drastic decrease of basidiocarps [13, 17, 25, 27, 35] or no basidiocarp formation. This competitive environment has a high number of microorganisms and diversity interacting with mycelia and it is suggested that a minimal community of these microorganisms would be necessary to stimulate fructification $[7,8,13,15,18,30,31$, $39,40]$. Also, there is no fructification under axenic cultivation or sterile casing layer in A. bisporus cultivation [9, 24]. However, Wood [42] was able to mimic microbial fructification stimulus under axenic cultivation in a sterile environment with sterile active coal as casing layer.

Pseudomonas genus, specifically Pseudomonas putida (Trevisan) Migula, has been reported as a stimulator of $A$. bisporus fructification $[6,8,18,19,31,43]$. However, it is not clear if the stimulus of fructification results from biocompounds excreted by a microorganism, stress due to the presence of microorganisms in the cultivation $[15,16,40$, 42] or a combination of them. If it was a combination of variables, it would be difficult to isolate which one would 
be responsible for stimulation, especially in casing layers based on peat moss that have a variable composition [14]. It makes the fructification stimulation process and the relationship of casing layer microbiological properties a challenging study. Therefore, stimulation and formation of primordia have not yet been clearly described and understood $[4,11]$.

Several methods to stimulate primordia in vitro under sterile conditions were described by Eger [9], Eger [10], Hume and Hayes [19], Long and Jacobs [23], Peerally [29] and Rainey and Cole [31]; however, they are laborious and time-consuming to be implemented, and some of them did not show consistent results [31, 42]. Agaricus bitorquis (Quél.) Sacc. [37], a species which is morphologically similar to A. bisporus but produces primordia in Petri dishes [33], has been used to study some cytological and biochemical events of primordium stimulation [32]. Therefore, it is a model species to analyze in vitro formation of primordia by stimulating bacteria in order to select potential primordium stimulating bacteria for A. bisporus cultivation and evaluate primordium stimulation process. Thus, the objective of this study was to characterize bacterial microbiota of casing layers from A. bisporus cultivation, isolate, identify and characterize the bacteria responsible for the stimulation of primordium and its action mechanism using A. bitorquis as a primordium stimulation model.

\section{Materials and Methods}

\section{Casing Layers}

The casing layer formulations were milled brown Irish moss peat (MBIM) + chalk (8:1), coded as CL1; used rockwool (UR), discarded after tomato production in a greenhouse + chalk (8:1), coded as CL2; UR + MBIM + chalk (6:2:1), coded as CL3; MBIM + ground dried pasteurized compost (MC) + chalk (6:3:1), coded as CL4; MBIM + MC + chalk (8:2:1), coded as CL5; and MBIM + MC + chalk (16:1:2), coded as CL6. Casing layers were collected in triplicate along three mushroom flushes of $A$. bisporus cultivation. A sample was analyzed for solid contents by drying in an oven with air circulation at $75{ }^{\circ} \mathrm{C}$ and another sample for bacterial community quantification.

\section{Quantification and Isolation of Bacterial Microbiota and of Pseudomonas spp.}

A bacterial community from different casing layers of $A$. bisporus (Sylvan A12) cultivation was collected and analyzed at the beginning of the first flush and at the end of the second and third flushes. To quantify the bacterial community, $10 \mathrm{~g}$ of each homogenized casing layer was diluted in
$90 \mathrm{~mL}$ of isotonic solution (Strength Ringer Solution Tablets; Difco ${ }^{\circledR}$ ), previously autoclaved for $15 \mathrm{~min}$ at $121{ }^{\circ} \mathrm{C}$, and incubated at $20 \pm 1{ }^{\circ} \mathrm{C}$ at $200 \mathrm{rpm}$ for $30 \mathrm{~min}$. A serial dilution of samples $\left(10^{0}-10^{-5}\right)$ was done with $100 \mu \mathrm{L}$ of each dilution distributed with a plate spreader on cultivation medium. Cultivation media were nutrient agar (NA) by Oxoid ${ }^{\circledR}$ for total bacterial growth and Pseudomonas isolation agar (PIA) by Difco ${ }^{\circledR}$ for Pseudomonas spp. growth on a $90 \mathrm{~mm}$ Petri dish. Each medium was kept at $25 \pm 1{ }^{\circ} \mathrm{C}$ for three days when the colony-forming units (CFU) per gram of dried casing layer were counted.

\section{Identification of $P$. putida}

Four biochemical assays, KOH string [3], gelatin hydrolysis, fluorescent pigment, and arginine dihydrolase, were used to identify P. putida among Pseudomonas spp. isolated in PIA $[12,20,21]$. For KOH string assay, a drop of potassium hydroxide at $3 \%$ was placed on a glass slide. A visible loopful of cells from a single colony was mixed into the drop. If the mixture became viscous within $60 \mathrm{~s}$ of mixing, it was considered $\mathrm{KOH}$-positive, an equivalent to the Gram-negative result for the Gram's method [3]. For gelatin hydrolysis assay, Pseudomonas aeruginosa (strain NCTC2744) was used as positive control and $P$. putida (strain AN202) as negative control. For fluorescent pigment, Escherichia coli (strain NCTC9001) was used as negative control and $P$. putida (strain AN202) as positive control on Pseudomonas agar fluorescent (PAF) medium (Merck ${ }^{\circledR}$ ) and ultraviolet light $(<260 \mathrm{~nm})$. For arginine dihydrolase assay, Pseudomonas tolaasii (strain NCPPB2192) was used as negative control and P. putida (strain AN202) as positive control. All strains were from Horticulture Research International (HRI) culture collection (Warwick University), Wellesbourne, England. Isolated $P$. putida strains were stored at $4{ }^{\circ} \mathrm{C}$ in PAF medium and malt-agar compost (MC) medium.

To prepare MC medium, $70 \mathrm{~g}$ of dehydrated compost was homogenized with $1000 \mathrm{~mL}$ of water and kept at $100{ }^{\circ} \mathrm{C}$ for $5 \mathrm{~min}$. The mixture was filtered in Miracloth $(22-25 \mu \mathrm{m})$ by Calbiochem ${ }^{\circledR}$ and $800 \mathrm{~mL}$ of the filtrate was mixed with $7.5 \mathrm{~g}$ of malt extract and $15 \mathrm{~g}$ of agar. After $\mathrm{pH}$ adjusted to 7.4, cultivation medium was autoclaved at $121{ }^{\circ} \mathrm{C}$ for $30 \mathrm{~min}$.

\section{Primordium Stimulation by $P$. putida}

To verify in vitro primordium stimulation by $P$. putida, a standard test with A. bitorquis (strain W19) from HRI culture collection with similar physiological characteristics and harvesting cycle to A. bisporus was used according to Rainey et al. [32].

A Petri dish with MC medium was inoculated with $P$. putida at four equidistant points from each other, located in 
Fig. 1 Quantity of bacteria (log of $\mathrm{CFU}$ ) per gram of dried casing layer (CL) isolated on nutrient agar medium along three mushroom flushes of Agaricus bisporus cultivation. CL1 = peat with milled brown Irish moss (MBIM) + chalk (8:1); CL2 = used rockwool (UR) from the tomato production substrate in greenhouse + chalk $(8: 1)$; $\mathrm{CL} 3=\mathrm{UR}+\mathrm{MBIM}+$ chalk (6:2:1); CL4 = MBIM + ground pasteurized dehydrated compost (MC) + chalk $(6: 3: 1)$; $\mathrm{CL} 5=\mathrm{MBIM}+\mathrm{MC}+$ chalk $(8: 2: 1)$ and $\mathrm{CL6}=\mathrm{MBIM}+\mathrm{MC}+$ chalk $(16: 1: 2)$

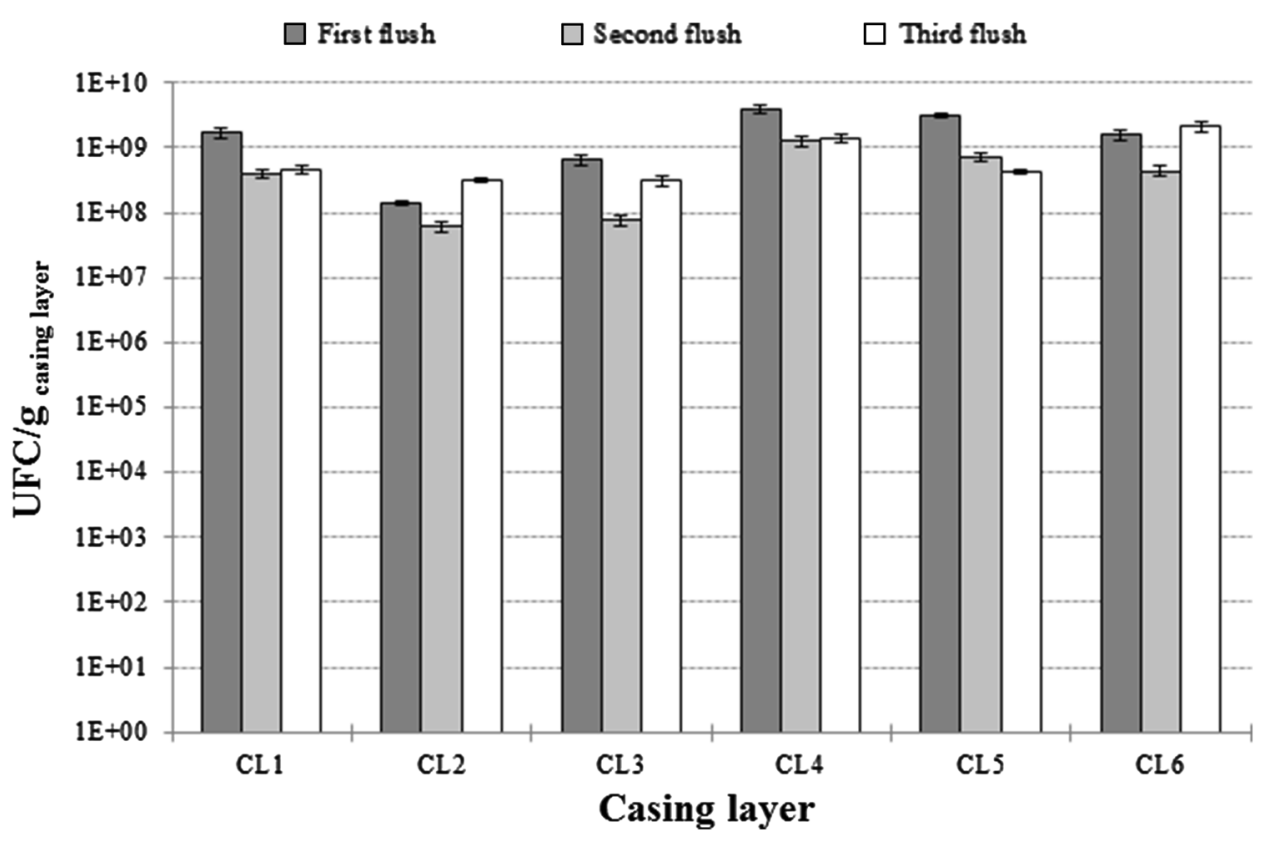

the peripheral area of the Petri dish in a cross shape at $30{ }^{\circ} \mathrm{C}$ for $24 \mathrm{~h}$. A disk containing mycelium of A. bitorquis was transferred to the center of the Petri dish and after mycelial growth of $5 \mathrm{~mm}$ over the bacterial colony, the mycelia were stimulated to primordium formation by decreasing temperature to $25^{\circ} \mathrm{C}$ for $24 \mathrm{~h} \mathrm{[32].} \mathrm{All} \mathrm{evalu-}$ ations were done in triplicate. Besides the $P$. putida strains isolated from casing layers, other bacteria from HRI culture collection were used as control such as $P$. putida (strain Paw8), $P$. putida (strain PRS2000), $P$. aeruginosa (strain ED8654), Pseudomonas fluorescens (strain SBW25), Enterobacteria cloacae (strain WS), Pseudomonas aereofaciens (strain U.t. cccc), Escherichia coli (strain ED8654), and Pseudomonas syringae (strain ATCC 19310). A. bitorquis primordia stimulated by $P$. putida were quantified, photographed and morphologically analyzed by scanning electron microscope.

\section{Analysis of the Action Mechanism of the Primordium Stimulation}

To analyze the action mechanism of primordium stimulation, bacteria with or without the ability to stimulate primordia were grown in $\mathrm{MC}$ medium at $30^{\circ} \mathrm{C}$ for $16 \mathrm{~h}$, transferred by scrapping it to $5 \mathrm{~mL}$ of sterile distilled water and agitated for $30 \mathrm{~s}$. Bacterial suspensions underwent the following chemical and physical treatments before using for primordium stimulation assay: (1) gamma radiation of 12.5-25.0 KGray for $200 \mathrm{~s}$; (2) bacterial filtration $(0.22 \mu \mathrm{m}$ pore filter); (3) autoclaving at $121{ }^{\circ} \mathrm{C}$ for $15 \mathrm{~min}$; (4) heating in dry hot block at $75^{\circ} \mathrm{C}$ for $3.5 \mathrm{~h}$; (5) addition of $6 \%$ sodium hypochlorite solution to bacterial suspension (2:1 at
$30{ }^{\circ} \mathrm{C}$ for $3 \mathrm{~h}$ ), centrifugation at $8000 \mathrm{~g}$ and washing twice with sterile distilled water; and (6) addition of absolute alcohol to bacterial suspension $\left(3: 1\right.$ at $30^{\circ} \mathrm{C}$ for $\left.4 \mathrm{~h}\right)$.

Each treated bacterial suspension $(10 \mu \mathrm{L})$ was placed at equidistant points of the peripheral area on MC medium, and primordium stimulation assay with $A$. bitorquis was replicated according to Raney et al. [32]. A non-chemically-or-physically-treated bacterial suspension of living $P$. putida $\left(1.32 \times 10^{9} \mathrm{UFC} \mathrm{mL}^{-1}\right)$ was the positive control and sterile water was the negative control for each tested bacteria. All evaluations were done in quadruplicate. The results were analyzed regarding to positive or negative primordium stimulation.

\section{Results and Discussion}

The total bacterial count in casing layers of A. bisporus cultivation is shown in Fig. 1. Bacterium quantity along mushroom cultivation flushes showed variations but it did not show any pattern. The higher quantity of bacteria in CL4, CL5 and CL6 (Fig. 1) may be related to the addition of pasteurized dehydrated compost in the casing layer which provides organic matter with the high amount of microorganisms even after pasteurization. Compost added in casing layer is often considered toxic for mushroom production $[5,8,9,17,22]$ but it increased bacterium quantity in the casing layer (Fig. 1). According to Maccanna [25], casing added compost (CAC) is a technique used to increase mycelial growth in casing layers homogenizing mushroom production, although contaminations could be promoted instead. In general, the first flush had a 
Fig. 2 Quantity of

Pseudomonas spp. (log of CFU) per gram of dried casing layer isolated on Pseudomonas isolation agar during three mushroom flushes of Agaricus bisporus cultivation.

CL1 $=$ peat with milled brown Irish moss (MBIM) + chalk (8:1); CL2 = used rockwool (UR) from the tomato production substrate in greenhouse + chalk (8:1); $\mathrm{CL} 3=\mathrm{UR}+\mathrm{MBIM}+$ chalk (6:2:1);

CL4 = MBIM + ground pasteurized dehydrated compost (MC) + chalk (6:3:1);

$\mathrm{CL} 5=\mathrm{MBIM}+\mathrm{MC}+$ chalk $(8: 2: 1)$ and

CL6 $=$ MBIM + MC + chalk $(16: 1: 2)$

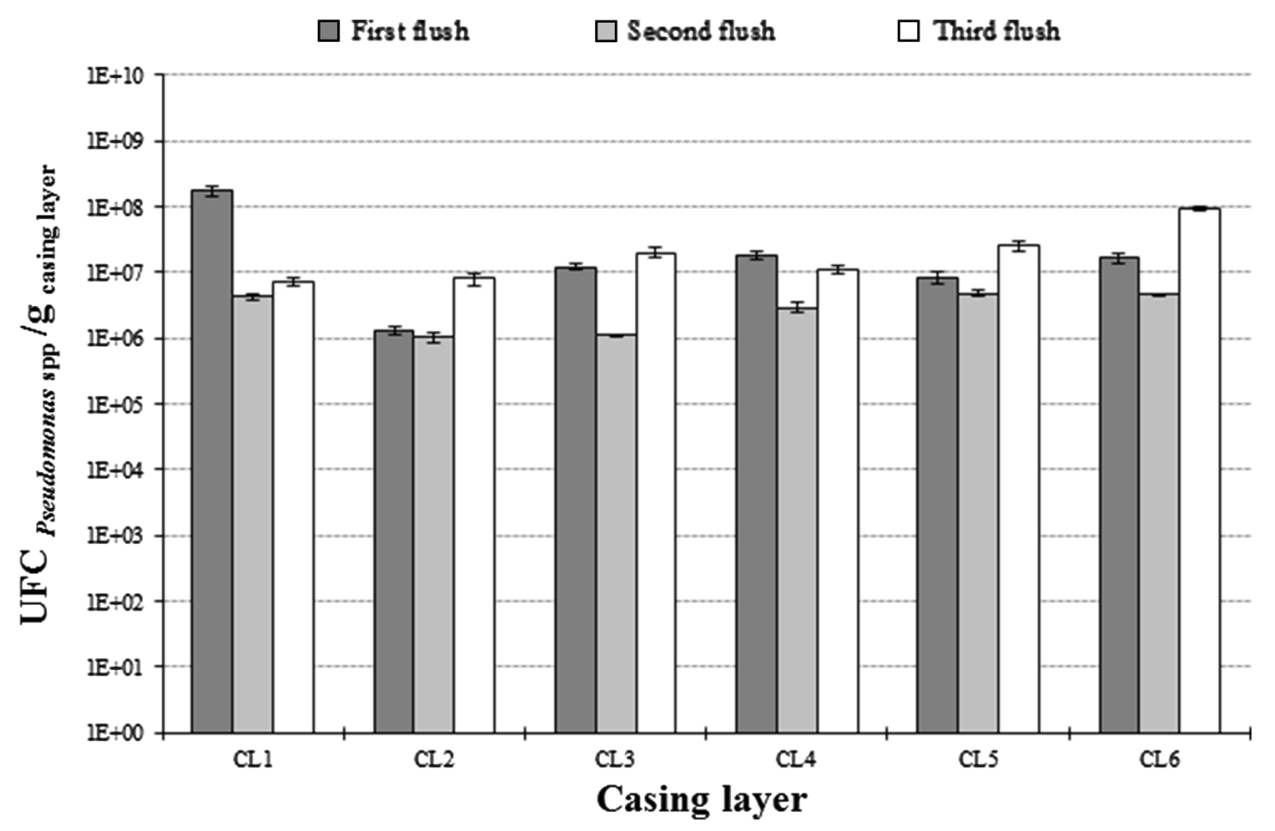

higher quantity of bacteria in all casing layers than the second flush (Fig. 1). However, there is no pattern detected as a general rule for quantity of bacteria along mushroom flushes.

All casing layers had Pseudomonas spp. in their microbial community (Fig. 2). In general, CL1, CL4, and CL5 had the highest quantity of Pseudomonas spp. (Fig. 2). Comparing quantity of Pseudomonas spp. among casing layers, CL1 was the highest for the first flush, CL1, CL5, and CL6 for the second flush, and CL6 for the third flush. Concentration of Pseudomonas spp. had no pattern detected along mushroom flushes for several casing layers.
It seems that there is a tendency of a higher quantity of Pseudomonas spp. in the first flush, lower in the second flush and higher again in the third flush. It is speculated that it is related to chemotaxis between mycelia and Pseudomonas spp. [26]. This is evidenced in our study when it is compared to the quantity of bacteria (Fig. 1) and the quantity of Pseudomonas spp. (Fig. 2). Pseudomonas spp. was predominant, representing 75-85\% of total bacteria in casing layers. Pseudomonas genus has chemotactic activity and, therefore, moves up to chemoattractants such as nutrients [2]. Also, besides this bacterium being robust and resistant to several inhospitable environments [38, 41], its
Fig. 3 Photo of Agaricus bitorquis mycelia on compost and malt extract agar stimulated by Pseudomonas putida $(a)$ with primordium formation $(b)$ and primordium abortion $(c)$

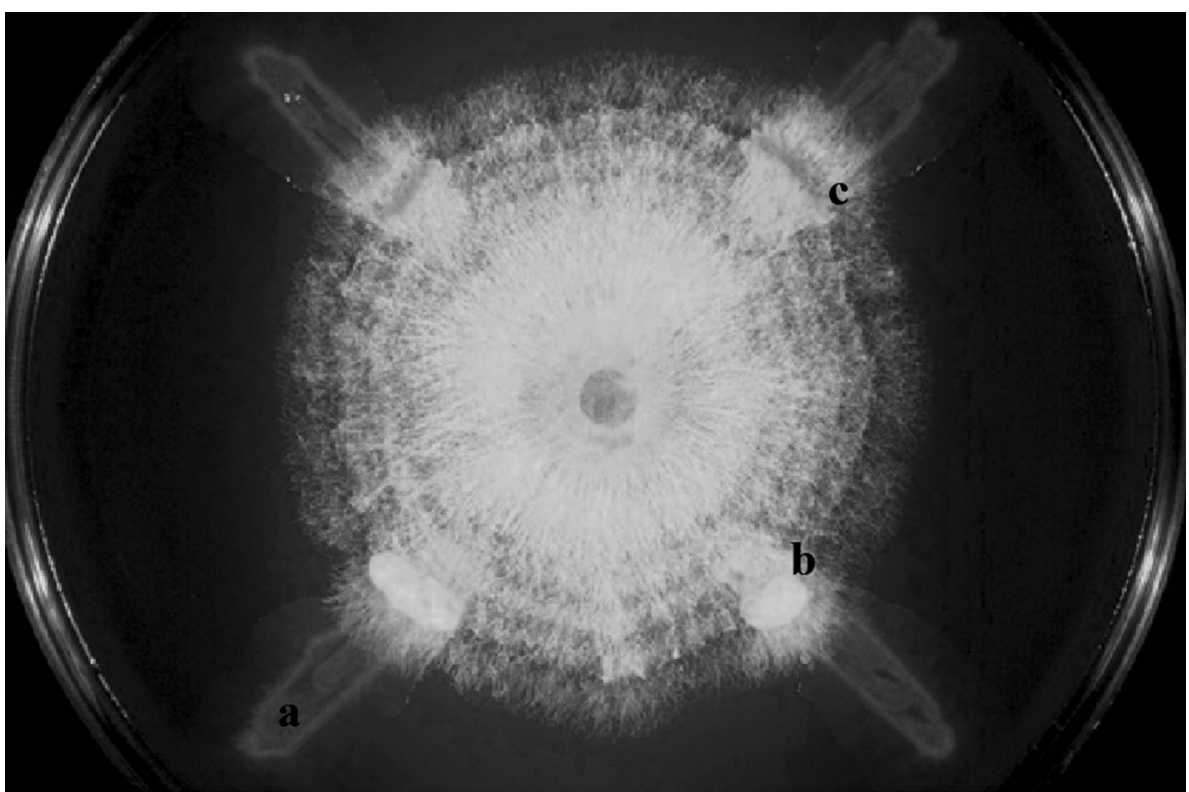


quantity is highly reduced in several stored and unused casing layers [4].

Among 81 bacteria isolated from all casing layers, 50 (61\% of all isolates) were identified as Pseudomonas genus and 10 (12\% of all isolates) were identified as P. putida. The last ones stimulated primordia in A. bitorquis assay. According to Samson et al. [36], Pseudomonas genus represents more than $50 \%$ of the microbial population of the casing layer, $47 \%$ of which may be P. putida. Colauto and Eira [4] reported that high concentration of bacteria, mainly Pseudomonas spp., occurs in casing layers along A. bisporus cultivation flushes instead of at the beginning of cultivation. Moreover, they found that most casing layers do not have high initial quantities of Pseudomonas spp. but along mushroom cultivation they increase greatly. In addition, several reports show that bacteria in casing layer increase during mushroom production of A. bisporus, and that it is an important characteristic to study fructification $[9,19,28,29$, 34]. It is suggested that mycelia exert a selective attraction of some microorganisms, mainly Pseudomonas spp., and a syntrophic mutualistic relationship between mycelia and bacteria might be occurring.

Ten $P$. putida isolated from A. bisporus cultivation stimulated primordia on A. bitorquis assay. Among these, three isolates (CP3, T1/4, and T2/6) stimulated primordia in $25 \%$ of the assay, one isolate (T2/6) stimulated $17 \%$, and six isolates (CP1/1, CP1/2, T2/5, T3/2, UR6/2, and UR7) stimulated $8 \%$. Primordium stimulation occurred heterogeneously although $A$. bitorquis stimulation primordium assay had four replications (stimulation places, Fig. 3a) in one Petri dish and this system had three replications, which reduced environmental and nutritional variables (Fig. 3). According to Wood [42], this suggests that there is the presence of non-identified variables acting on fructification stimulation assay. On the other hand, Peerally [30] suggested that, in order to keep a constant production of basidiocarps, there is a sequential and hierarchical formation and development of basidiomas on mushroom cultivation. Also Babikova et al. [1] reported a mycelial network acting as a conduit for signaling herbivore attack between plants, demonstrating the mycelial ability of communicating information along the mycelia. Considering what was stated above and because most primordium stimulation assay had showed abortion of primordium formation after primordia are formed, it suggests that the development of primordia could inhibit the formation of others (Fig. 3b, c). We suppose that when mycelia are undergoing any stimulation, they responded as one, affecting primordium formation and development.

Primordium stimulation on A. bitorquis assay was also tested by randomly choosing bacteria from HRI culture collection. P. putida (strain Paw8) that was isolated from noncasing layer sources, caused a modification in the mycelial

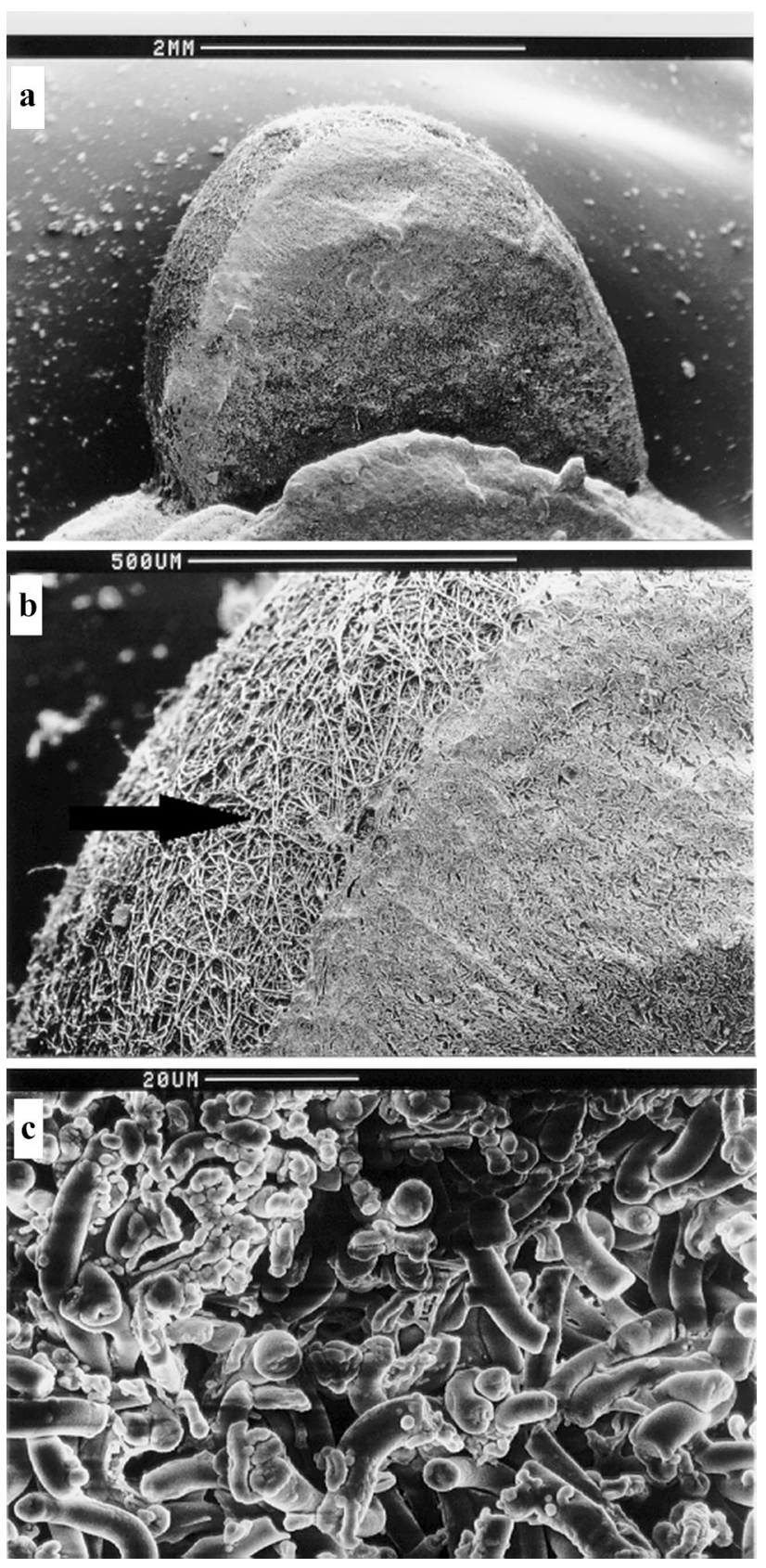

Fig. 4 Micrograph of vertical cut of an Agaricus bitorquis primordium stimulated by Pseudomonas putida by scanning electron microscope. Photo: a overview of primordium; b primordium enlargement showing texture of external-oriented-tissue surrounding internal-non-oriented-mycelial mass; $\mathbf{c}$ enlargement of indistinct internal-non-oriented-mycelial mass

shape and a primordium stimulation that was aborted afterwards, making evident that $P$. putida is an inducer of fructification. Conversely, P. putida (strain PRS2000), used in bioremediation, caused inhibition of mycelial growth and no primordium stimulation. $P$. aeruginosa, $P$. fluorescens, $E$. cloacae, P. aereofaciens, and E. coli inhibited mycelial growth and did not stimulate primordia. Pseudomonas 
syringae (strain ATCC 19310) did not present any visible effect on mycelial growth such as mycelial inhibition or primordium stimulation. It is suggested that only $P$. putida, probably selected by chemotaxis in the mushroom cultivation, was suitable for primordium stimulation.

The micrograph of $A$. bitorquis primordium induced by $P$. putida (Fig. 4a) shows a formation of differentiated tissue surrounding the non-oriented mycelial mass (Fig. 4b, c), a characteristic of developed basidiocarps. It is suggested that the formed structure is a primordium instead of a non-organized mycelial mass from an antagonist region of the mycelium due to the bacterial presence, or a mycelial aggregate from the mycelial structural formation that occurs just before primordium formation.

For analysis of the action mechanism of the primordium stimulation, bacterial suspensions underwent chemical and physical treatments before primordium stimulation were not able to stimulated primordia in A. bitorquis stimulation primordium assay. It is suggested that biocompounds from those bacteria were not able to stimulate primordia in $A$. bitorquis assay and, therefore, were not responsible for primordium stimulation. On the other hand, living bacterial suspension of $P$. putida $\left(1.32 \times 10^{9} \mathrm{UFC} \mathrm{mL}^{-1}\right)$ was able to stimulate primordia. This reinforces that in vivo interaction between mycelia and bacteria is mandatory to stimulate $A$. bitorquis primordia.

It was concluded that Pseudomonas spp. corresponds to $75-85 \%$ of bacterial population of the casing layers in $A$. bisporus cultivation and among those $12 \%$ are $P$. putida. Interaction of living $P$. putida with $A$. bitorquis mycelia is capable of stimulating primordial instead of non-living bacterial suspensions. Stimulation of $A$. bitorquis primordia does not imply or is related to mycelial growth inhibition, but it suggests a hierarchical relation of primordium succession and development.

Acknowledgments The authors thank the National Council of Technological and Scientific Development $(\mathrm{CNPq})$ for the doctorate fellowship, Paulista State University (UNESP) and the Horticulture Research International

\section{Compliance with Ethical Standards}

Conflict of interest The authors declare that they have no conflict of interest.

\section{References}

1. Babikova Z, Gilbert L, Bruce TJA, Birkett M, Caulfield JC, Woodcock C, Pickett JA, Johnson D (2013) Underground signals carried through common mycelial networks warn neighbouring plants of aphid attack. Ecol Lett 16(7):835-843. doi:10.1111/ele.12115

2. Brennerova MV, Crowley DE (1994) Direct detection of rhizosphere-colonizing Pseudomonas sp. using an Escherichia coli
rRNA promoter in a Tn7-lux system. FEMS Microbiol Ecol 14(4):319-330. doi:10.1111/j.1574-6941.1994.tb00117.x

3. Carlone GM, Valadez MJ, Pickett MJ (1982) Methods for distinguishing Gram-positive from Gram-negative bacteria. J Clin Microbiol 16(6):1157-1159

4. Colauto NB, Eira AF (1998) Quantitative evaluation of the bacterium community in the casing layer on Agaricus bisporus. Energ Agric 13(2):15-26

5. Couvy J (1972) Étude de l'induction de la fructification chez Agaricus bisporus (Lange) Sing (= Psalliota hortensis Cke): action du glucose. C R Hebd Séances Acad Sci 274: 2475-2477

6. Cresswell PA, Hayes WA (1978) Further investigations on the bacterial ecology of the casing layer. Mushroom Sci 11:347-359

7. Curto S, Favelli F (1972) Stimulative effect of certain microorganisms (bacteria, yeasts, microalgae) upon fruit-body formation of Agaricus bisporus (Lange) Sing. Mushroom Sci 6:67-74

8. Eger G (1972) Experiments and comments on the action of bacteria on sporophore initiation in Agaricus bisporus. Mushroom Sci 8:719-725

9. Eger G (1962) The "Halbschalentest", a simple method for testing casing materials. Mushroom Growers Assoc Bull 148:159-168

10. Eger G (1963) Untersuchungen zur fruchtkörperbildung des kulturchampignons. Mushroom Sci 5:314-320

11. Fermor T, Lincoln S, Noble R, Dobrovin-Pennington A, Colauto $\mathrm{N}$ (2000) Microbiological properties of casing. In: Van Griensven LJLD (ed) Science and cultivation of edible fungi. CRC, Maastricht, pp 447-454

12. Fett WF, Wells JM, Cescutti P, Wijey C (1995) Identification of exopolysaccharides produced by fluorescent Pseudomonads associated with commercial mushroom (Agaricus bisporus) production. Appl Environ Microbiol 61(2):513-517

13. Flegg PB, Wood DA (1985) Growth and fruiting. In: Flegg PB, Spencer DM, Wood DA (eds) The biology and technology of the cultivated mushroom. Wiley, Chichester, pp 141-177

14. Gaze R (1996) Pegging the variables: casing. Mushroom J 561:24

15. Hayes WA (1981) Interrelated studies of physical, chemical and biological factors in casing soils and relationships with productivity in commercial culture of A. bisporus Lange (Pilat). Mushroom Sci 11:103-129

16. Hayes WA (1972) Nutritional factors in relation to mushroom production. Mushroom Sci 8:663-674

17. Hayes WA (1974) The casing layer. Mushroom Growers' Association, Leeds

18. Hayes WA, Nair NG (1974) Effects of volatile metabolic byproducts of mushroom mycelium on the ecology of the casing layer. Mushroom Sci 9:259-268

19. Hume DP, Hayes WA (1972) The production of fruit-body primordia in Agaricus bisporus (Lange) Sing. on agar media. Mushroom Sci 8:527-532

20. Jain VB, Singh RN, Singh SP (1983) Selection of casing medium for cultivation of white button mushroom. Progress Hortic 15(1-2):126-128

21. Klein PH (1996) Microbiology, 3rd edn. Times Mirror, Dubuque

22. Lambert EB (1938) Principles and practice of mushroom growing. Bot Rev 4:397-426

23. Long PE, Jacobs L (1974) Aseptic fruiting of the cultivated mushroom, Agaricus bisporus. Trans Br Mycol Soc 63(1):99-107

24. Long PE, Jacobs L (1969) Some observations on $\mathrm{CO}_{2}$ and sporophore initiation in the cultivated mushroom. In: Mushroom science VII. Proceedings of the international congress on mushroom science, Hamburg, pp 373-384

25. Maccanna C (1984) Comercial mushroom production. Foras Taluntais, Dublin 
26. Miller N, Gillespie JB, Doyle OPE (1995) The involvement of microbiological components of peat based casing materials in fructification of Agaricus bisporus. Mushroom Sci 14:313-321

27. Nair MC, Gokulapalan CDL (1994) Mushroom biotechnology. Scientific Publishers, Jodhpur

28. O'Donoghue-Maguire DC, Ryan JP (1991) Influences of a wide range of bacteria, actinomycetes and fungi on mycelial growth of Agaricus bisporus (Lange), Sing and special fruiting requeriment of A. bisporus. In: Maher MJ (ed) Science and cultivation of edible fungi. Balkema, Rottedam, pp 753-759

29. Peerally A (1981) A petri-plate agar technique for obtaining primordia in Agaricus bisporus (Lange) Sing. Mushroom Sci 8:153-158

30. Peerally A (1978) Sporophore initiation in Agaricus bisporus and Agaricus bitorquis in relation to bacteria and activated charcoal. Mushroom Sci 11:611-639

31. Rainey PB, Cole ALJ (1987) Evidence for the involvement of plasmids in sporophore initiation and development in Agaricus bisporus. Dev Crop Sci 10:235-248

32. Rainey PB, Cole ALJ, Fermor TR, Wood DA (1990) A model system for examining involvement of bacteria in basidiome initiation of Agaricus bisporus. Mycol Res 94(2):191-195. doi:10. 1016/S0953-7562(09)80612-6

33. Raper CA (1976) Sexuality and the life-cycle of the edible wild Agaricus bitorquis. J Gen Microbiol 105:135-151. doi:10.1099/ 00221287-95-1-54

34. Reddy MS, Patrick ZA (1990) Effect of bacteria associated with mushroom compost and casing materials on basidiomata formation in Agaricus bisporus. Can J Plant Pathol 12(3):236-242. doi:10.1080/07060669009500993

35. Reijnders AFM (1954) Le development des carpophores dans le genre Agaricus. Mushroom Sci 2:11-15

36. Samson R, Houdeau G, Khanna P, Guillaumes J, Olivier JM (1987) Variability of fluorescent Pseudomonas populations in compost and casing soils used for mushroom cultures. Dev Crop Sci 10:19-25

37. Smith JF, Love ME (1989) A tropical Agaricus with commercial potential. Mushroom Sci 12:305-315

38. Stanier RY, Pallerroni NJ, Doudoroff M (1966) The aerobic Pseudomonas, a taxonomic study. J Gen Microbiol 43(2):159271

39. Verbeke MN, Overstyns A (1991) Interralationships between activated charcoal, carbon dioxide, oxalate and iron chemistry for fructification of Agaricus bisporus. In: Maher MJ (ed) Science and cultivation of edible fungi. Balkema, Rottedam, pp 737-746

40. Visscher HR (1978) Fructification of Agaricus bisporus (Lge.) Imb. in relation to the relevant microflora in the casing soil. Mushroom Sci 10:641-664

41. White D (1995) The physiology and biochemistry of prokaryotes. Oxford University, Oxford

42. Wood DA (1976) Primordium formation in axenic cultures of Agaricus bisporus (Lange) Sing. J Gen Microbiol 95:313-323

43. Wood DA (1978) Studies on primordium initiation in Agaricus bisporus and Agaricus bitorquis (syn. edulis). Mushroom Sci 10:565-586 